\title{
Government Spending and Inclusive-Growth Relationship in Nigeria: An Empirical Investigation
}

\author{
Bashir Olayinka Kolawole*
}

\begin{abstract}
This study has investigated the relationship between government spending and inclusive growth in Nigeria over the period 1995 to 2014. Specifically, it examined how, and to what extent, government spending on education, government spending on health, economic freedom, public resource use, and real GDP growth rate have impacted on inclusive growth in the country. It used the Dickey-Fuller GLS unit root test to ascertain the order of integration of the series. Consequently, through the Auto-Regressive Distributed Lag (ARDL) bound testing technique, the study found that in the long-run government spending on health, economic freedom, public resource use and real GDP growth rate had significantly positive influence on inclusive growth. In the short-run, however, only real GDP impacted significantly on inclusive growth while other variables were not significant in causing inclusive growth. Thus, in conclusion, government spending in the form of redistributive spending on health propelled inclusive growth in Nigeria.
\end{abstract}

Keywords: ARDL; cointegration; government spending; inclusive growth; Nigeria.

JEL Classification: B52, H50, O47

\section{Introduction}

The necessity of economic growth for development is a notion that cuts across the literature. The sufficiency of such growth for guaranteed improved social well-being of the citizen, or its efficient distribution is, however, far from reality. This is due to the fact that economic growth by itself is not necessarily sufficient. Such growth needs to be sustainable, sustained and inclusive ${ }^{1}$. This follows from the fact that economic opportunities must be created by growth and should be made available to all, particularly the poor. Such that, economic growth must sustainably be equal and help

\footnotetext{
* Bashir Olayinka Kolawole is at Department of Economics, Faculty of Social Sciences, Lagos State University, Lagos, Nigeria.
} 
reduce poverty ${ }^{2}$. Thus, the desire for inclusive growth has called for concern among scholars, policy makers and international bodies across the globe.

Meanwhile, for economic growth to happen, increasing government spending is important ${ }^{3}$. This is in the sense that productive government spending is a fundamental variable needed to explain differences in economic growth among countries ${ }^{4}$. It is the spending, in the form of public infrastructure, property rights, order, security, public transports, water and electricity networks that enhances private capital productivity 5 . However, since growth in itself does not guarantee improved social well-being of the citizen, or its efficient distribution, then the inclusiveness of such growth is paramount. Such that, promoting inclusive growth through redistribution strategy may directly enhance income of the poorest groups across the globe. This may also help alleviate problems of non-sustainability and non-inclusiveness associated with the current commodity-based growth faced by Nigeria, and many African countries ${ }^{6}$.

In recent time, economic growth episode in Nigeria recorded an impressive macroeconomic performance. This is evident in the gross domestic product (GDP) growth from 0.47 per cent in 1999 to 5.39 per cent in 2013, and real GDP of 941.46 billion in 2013. Unlike what it used to be, the growth of the oil sub-sector has not been relatively encouraging as it had 3.4 per cent, -2.3 per cent and 5.3 per cent respectively in 2011, 2012 and 20137. The economic downturn notwithstanding, yet Nigeria is bedevilled with the challenge of inclusive growth ${ }^{8}$, as about 110 million Nigerians live below poverty line despite several economic policies and poverty alleviation programmes geared towards welfare improvement by past governments of the country ${ }^{9}$. This is in addition to the fact that the country is among the ten countries in the world with the largest number of illiterate adults (see Education for All Global Monitoring Report, 2010) coupled with the information that 63 per cent of the population lived on less than USD 1 per day in 2011 (see African Economic Outlook, 2012).

Meanwhile, several discussions relating to the link between government spending and economic growth in Nigeria have been put forward in the literature. For example, one of the very recent contributions is that of Aregbeyen and Kolawole (2015) who, like many other studies ${ }^{10}$, established a positive significant relationship between the two variables in the short-run in Nigeria. However, it is a common knowledge in recent time that one of the key factors that determine economic growth is institu$\operatorname{tion}^{11}$. An inclusion of institution or institutional quality in the work of Aregbeyen and Kolawole (2015) would have probably revealed more robust results. Also, analysis of the relationship between variables in both the short-run and long-run is well carried out using the cointegration technique. The cointegration technique provides useful procedures for causal analyses regarding the long-run relationships and shortrun dynamic interactions among variables. Probably the adoption of a cointegration technique would have also helped establish a more reliable long-run estimate. Thus, in order to make contribution to the open-ended discussion, the present study finds 
justification by examining the relationship between government spending and inclusive growth in the country. For the reason to capture the growth dividend, as well as the MDGs influence on developmental activities in Nigeria, the study covered the period from 1995 to 2014.

Nevertheless, the importance of this research also stemmed from the desire of the Nigerian government for inclusive growth via potent economic policies in the country. This follows from the fact that economic and social policies have failed to help improve the level of literacy and stock of infrastructure in Nigeria over the years ${ }^{12}$. Also, it is germane that the poor, alongside the rich, must participate and benefit from economic growth through redistributive and transformative public expenditures needed for breaking the poverty-cycle. Such goal could be achieved through quality institution, as well as pro-poor productive government spending in the form of broad-based expenditure on education, health and infrastructure. Therefore, this study proffers policy-relevant suggestions that would sensitize the government on the need to address certain problems militating against the achievement of inclusive growth in Nigeria.

After this introductory part, the other aspect of the paper is structured as follows. Section two presents an overview on the Nigerian economy. Section three reviews the literature while section four provides the methodology. Section five presents and discusses the empirical results as section six concludes the study with policy implications.

\section{The Nigerian Economy: An Overview}

Nigeria has the largest economy in Africa following the rebasing of its GDP from 1990 to 2010. Over the past decade, the country has experienced impressive sustained growth rate with minimum of 6.2 per cent. However, the benefits of the growth have not sufficiently trickled down to the poor as reflected in the increasing levels of poverty and unemployment in the country. Specifically, unemployment rate climbed to 24 per cent in 2012 from 21 per cent in 2010. Also, the country ranked low in human development given Human Development Index (HDI) score of 0.423 in 2009, ranking the country at 142 nd out of 169 countries, and 0.471 in 2012. These scores were even below the sub-Saharan Africa's average of $0.475^{13}$.

Meanwhile, concerted efforts at achieving inclusive growth in Nigeria have been intensified over the years from government to government. For instance, the issue of job creation and poverty reduction has earned the establishment of agencies like the National Directorate of Employment (NDE), the National Poverty Eradication Programme (NAPEP), the Small and Medium Enterprises Development Agency (SMEDAN), the Agricultural Transformation Agenda (ATA), the Employment Programmes of the Subsidy Reinvestment and Development Programme (SURE-P), Care 
of the POOR (COPE), the Maternal and Child Health Care (MCH) programme and a health-fee waiver for pregnant women and children under five, Community-based Health Insurance Scheme, and the United Nations Millennium Development Goals (MDG) Acceleration Framework (MAF). Also, as a successor to the Health Sector Reform Programme (2003-2007), the 2010-2015 National Strategic Health Development Plan (NSHDP) was launched in 2010 with the assurance of harmonising efforts of the government and its development partners.

The resultant benefits of the efforts were, however, identified in both the health and education sub-sectors. Specifically in the health sub-sector, infant mortality rate dropped from 126 per one thousand live births in 1990, to 88 in 2008, and 78 in 2012. Also, maternal mortality rate reduced from 1100 per hundred thousand live births in1990, to 820 in 2005, 545 in 2008, and 630 in 2012. The prevalence of HIV/AIDS declined from 5.8 per cent in 2001, to 4.6 per cent in 2008, 4.1 per cent in 2010 and 3.4 per cent in 2012. A major achievement on record in the education sub-sector is the implementation of the Universal Basic Education Programme. The programme caused an increase in primary school enrolment from 84 per cent in 2000 to 80 per cent in 2004, 89 per cent in 2005 and 90 per cent in 2009. Also, the total secondary school enrolment rate improved from 34 per cent in 2000 to 38 per cent in 2009. However, in 2012, the UNESCO's Education for All Global Monitoring Report declared that an estimated 10.5 million Nigerian children were out of school and 26 per cent of those enrolled did not complete the primary cycle. It points to the fact that about 72.1 per cent of the population in the 15 to 24 age bracket were literate. This followed from the report in 2010 that Nigeria ranked among the ten countries in the world with the largest number of illiterate adults (see African Economic Outlook, 2012, 2014).

Essentially, the key challenges to human development and progress towards achieving inclusive-growth in Nigeria include limited institutional capacities. As such, in the attempt to nip this in the bud, various institutional reforms were designed and implemented. These included the Public Service Reform, the Procurement Reform, and Fiscal Responsibility, the Nigeria Extractive industries Initiatives (NEITI), the Anti-corruption Reform which extended to the Independent Corrupt Practices and Other Related offences Commission (ICPC), as well as the Economic and Financial Crimes Commission (EFCC).

\section{Literature Review}

\section{Concept and Measure of Inclusive-Growth}

Inclusive growth has been conceptualised with different perspectives of how human well-being is viewed and analyzed. For example, World Bank (2009) defined inclu- 
sive growth as a sufficient growth that includes the largest part of the country's labour force and which can take large numbers out of poverty in an economy. This definition is pro-labour. But then, labour force, in most cases, always refers to the workers in the formal sector where the population is not a true representation of either the total work force or the general population. Thus, World Bank (2009) definition that based inclusive growth on certain part of the labour force is narrow. The definition of inclusive growth should address issues that relate to the overall population in an economy, and must not discriminate.

Meanwhile, in 2014, the Catholic Agency for Overseas Development (CAFOD) emphasised that inclusive growth is distinct from standard economic growth and its approach is different from the standard approaches of growth. According to CAFOD (2014), an inclusive growth: should benefit the most marginalised by reducing poverty and inequality, is more than about income, not just outcomes but about participation, and requires sustainable growth. In order to achieve these goals, the following key strategic ingredients were enumerated: investment in human capital, job creation, structural transformation and broad-based growth, progressive tax policies, social protection, non-discriminatory social inclusion and participation, and strong institutions. However, due to the distinct nature of the concept and lack of clarity about how the approach differs from the standard growth approach, CAFOD (2014) recommended to donors and governments who desire inclusive growth to: develop a clear and explicit definition, objectives, strategies, guidelines and indicators on how to achieve the concept, as well as prioritising small businesses.

In review of the definition and explanation of inclusive growth provided by CAFOD (2014), the concept is a bit broad considering the issues of unemployment, poverty and inequality. The point at which the world converges in the recent time is on reducing poverty and inequality. However, the issue of marginalisation is paramount in the sense that every region and community would claim to be marginalised if the measure of inclusive growth is concentrating on the most marginalised. Also, it would be difficult to obtain generally acceptable criteria that can be used to categorise a particular section of the country or region as the most marginalised. Furthermore, to be inclusive, the benefit of growth must not be discriminatory as it should be enjoyed together by all the citizens including the rich, the near rich, the middle class, the near poor, and the poor.

As regards measure of inclusive growth, a number of frameworks have been put forward by scholars across countries without a universally accepted indicator for the concept. For example, the principle of social welfare function was constructed by Ali and Son (2007) to measure inclusive growth. The authors argued that economic growth is inclusive if the social opportunity function is enhanced. By social opportunity, Ali and Son (2007) used health and education accessibility in relation to income distribution to indicate whether there is a pro-poor social improvement or not. Thus, by implication, if income is evenly distributed in such a way that the poor has an 
improved access to health and education, then growth is inclusive. A disadvantage of this measure is the fact that income distribution is not sufficient to cause improvement in health and/or education of the poor. For instance, assuming the authors incorporated employment generation and participation, a broader measure would have been obtained. If the poor is gainfully employed in addition to health and education accessibility, social opportunity would be more meaningful.

Meanwhile, Klasen (2010) adopted a relatively broader measure to conceptualise inclusive growth. Using income and non-income indicators of well-being such as access to education and health, nutrition, and social integration, the author proposed a decline in inequality in the non-income dimension of well-being as a measure of inclusion. However, this measure is difficult to compute due to the non-availability of the several non-income indicators required, especially in the developing countries.

Furthermore, Suryanarayana (2013) conceptualised inclusion as an improvement in the fraction of bottom half of the population in the mainstream band. As a relative perception of deprivation, the author noted, an individual whose level of income is below a benchmark of say 60 per cent of the median is considered deprived otherwise the individual is included in the mainstream. Thus, this approach described a measure of inclusion as a proportion of bottom half of the population in the 'mainstream band'. The drawback in this approach is how to classify the mainstream and the bottom half. To be a good measure, an indicator must be unambiguous and easy to measure.

In summary, inclusive growth has been conceptualised differently by authors and organizations as reviewed above. The review shows clearly that a unanimous definition and/or measure does not exist for inclusive growth, yet. However, some key elements that are fundamental and needed to be addressed for growth to be inclusive include growth, poverty, inequality, benefits of growth, participation, opportunity, productive employment, capabilities/empowerment, gender inequality, access to infrastructure, social protection, targeted policies, basic social services, good governance, and barriers for investment. But then it is important to note that irrespective of the definitions and measures ascribed to inclusive growth, there would always be a disagreement due to cross-countries' political, socio-cultural and socio-economic differences.

In essence, this paper conceptualises inclusive growth ${ }^{14}$ to be GDP growth that is participatory in production and which the benefit is non-discriminatorily and fairly enjoyed by everybody whether rich, near rich, middle class, near poor or poor in the economy. Thus, inclusive growth must uplift everybody at the same time, and in different ways. However, due to the reasons of health, difference in skills, individual preferences for leisure and work, and other factors, inclusive growth's opportunities and benefits may not accrue to all the citizens equally. 
Review of Selected Previous Studies on Government Spending and Economic Growth

The relationship between government spending and economic growth has been discussed in many studies at different periods. While some empirical studies ${ }^{15}$ revealed positive relationships between productive government spending and economic growth; others which include Landau (1986), Grier and Tullock (1989), Evans and Karras (1994) established a negative nexus; as yet, another group of studies ${ }^{16}$ reported 'no or difficult to isolate' cases.

Meanwhile, for Jordan, AlBataineh (2012) examined the impact of government expenditures on economic growth over the period 1990 to 2010. The study revealed that aggregate government expenditure impacted positively on GDP growth in the country. Similarly, Alshahrani and Alsadiq (2014) empirically examined the effects of several components of government expenditures on economic growth in Saudi Arabia from the period 1969 to 2010. Results from the study showed that healthcare expenditure, public and private investments propelled growth in the country. The study further suggested that government spending on housing could enhance shortrun production.

For Nigeria, Ogiogio (1995) reported a long-term association between government spending and economic growth with more impact from recurrent spending in the country. Also, Fajingbesi and Odusola (1999) found that real government capital spending had a strong positively significant impact on real output whereas real government recurrent spending affected growth mildly in the country. Akpan (2005), however, concluded that there was no significant relation between most components of government spending and economic growth in Nigeria. Meanwhile, Ighodaro and Oriakhi (2010) reported an economic growth-propelling variable in total government expenditure and its components such as general administration, community and social services. On the contrary, Nurudeen and Usman (2010) showed that total capital spending, total recurrent spending, and government spending on education had negative impact on economic growth in the country. However, government spending on health, transport and communication had positive effects. Also, Adeniyi and Bashir (2011) showed that governments spending on agriculture, education, and structural adjustment programme impacted positively on economic growth in the country. In the short-run, according to Usman et al. (2011), public spending had no impact on growth, but a relationship was established between the two variables in the long-run.

Furthermore, Adewara and Oloni (2012) reported that during the period 19602008 public spending on health and agriculture enhanced economic growth in Nigeria as against zero effect from public spending on education. Yet, Nasiru (2012) reported that long-run relationship did not exist between the variables but government spending Granger-caused economic growth over the period 1961-2010 in the country. Also, Muse, Olorunleke and Alimi (2013) claimed that there was no long-run association between Federal government spending and real per capita GDP from 1961 to 
2011 in Nigeria. However, Garba and Abdullahi (2013) found a significant positive long-run association between the variables as both Granger-caused each other during the period 1970-2008. As Oni, Aninkan and Akinsanya (2014) confirmed that capital and recurrent spending influenced growth positively in the period 1980-2011 in the country.

Also, over the period from 1980 to 2012, Kolawole, Omobitan and Yaqub (2015) established a positively significant relation between government spending on health and per capita growth in the country, as against a negatively significant association between government spending on education and per capita GDP. For the same period, Kolawole and Odubunmi (2015) found that government capital spending significantly impacted positively on economic growth in Nigeria.

Thus, from the forgoing studies, it is established that the link between government spending and economic growth could be a positive, negative, or no-causal one.

\section{Methodology}

Given this paper's conceptualisation of inclusive growth due to the lack of a clear and unanimous definition, robust data, ${ }^{17}$ and the economic context of a particular country $^{18}$, GDP per capita based on Purchasing Price Parity (PPP) is adopted as proxy for inclusive growth. This is because GDP per capita incorporates economic growth and total population of the citizen. In the attempt to establish the relationship between government spending and inclusive growth in Nigeria, a single linear equation was estimated. In the process, the stationarity of the data series was carried out through the Dickey-Fuller generalised least squares (DF-GLS) ${ }^{19}$ unit root test developed by Elliot, Rothenberg and Stock (1996). This was necessary due to the satisfactory performance of the method in small samples. Furthermore, given the relevance of simultaneous evaluation of both the short-run and long-run relationships, the ARDL cointegration technique was employed. The choice of ARDL stemmed from the fact that among different coitegration approaches ${ }^{20}$, the ARDL technique is relatively important and useful. As developed by Pesaran and Shin (1999) and extended by Pesaran et al (2001), the ARDL has certain advantages over other cointegration methods. Firstly, it does not require that all variables under consideration be integrated of the same order as it can be applied when the under-lying variables are integrated of order zero, order one or fractionally integrated. Secondly, ARDL test is relatively more efficient in the case of small and finite sample data sizes. Thirdly, by applying the ARDL technique, an unbiased estimate of the long-run model can be obtained ${ }^{21}$. Fourthly, all variables in the model are assumed to be endogenous. Fifthly, the shortrun and long-run coefficients of the model are estimated simultaneously. Meanwhile, for the necessity of uniformed scale of measurement and consistent interpretation of results, all variables, except public spending on health and real GDP which were in 
growth rates, were transformed to their respective natural logarithms. All estimations and statistical decisions were based on 5 per cent level of significance.

\section{The Models}

Given that a strong country-specific combinations of growth and distribution policies promote inclusive growth (Mckay \& Sumner, 2008) and reduces poverty (Bourguignon, 2004), this study captured the effect of productive government spending on growth through the theoretical endogenous growth models of Barro (1990) as specified in equations (1) and (2). That is,

$$
\begin{aligned}
& y=f(k, \mathrm{~g})=A k^{\alpha} \mathrm{g}^{1-\alpha} \\
& y=f\left(k, \mathrm{~g}_{1}, \mathrm{~g}_{2}\right)=\left[\alpha k^{-\rho}+\beta \mathrm{g}_{1}^{-\rho}+\gamma \mathrm{g}_{2}^{-\rho}\right]^{-1 / \rho} \\
& \alpha>0, \beta \geq 0, \gamma \geq 0, \alpha+\beta+\gamma=1, \text { and } \rho \geq-1
\end{aligned}
$$

where $g$ is government spending $\mathrm{g}_{1}$ and $\mathrm{g}_{2}$ represent productive government spending and unproductive government spending, respectively.

Thus, in the attempt to empirically represent the impacts of government spending (Gs), as proxied by government spending on education (Gse) and government spending on health (Gsh), on inclusive growth (y), following Ali and Son (2007) and Adedeji et al (2013) on the link between inclusive growth and contribution to inclusiveness (productive government spending), the re-specification of (1) or (2) in the functional and the natural log linear transformation forms are stated below respectively in (3) and (4) as:

$$
\begin{aligned}
& y_{t}=f\left(G s_{t}\right)=f\left(G s e_{t}, G s h_{t}\right) \\
& \ln _{t}=\beta_{0}+\beta_{1} \ln G s e_{t}+\beta_{2} \ln G s h_{t}+\epsilon_{t}
\end{aligned}
$$

Meanwhile, since institutions matter for growth, the study follows North (1990) and Beland and Tiagi (2009) on the nexus between inclusive growth and institutional quality in expression (5) below as,

$$
\Delta G d p_{i}=\beta_{0}+\beta_{1}\left(R d_{i}\right)+\beta_{2}\left(E f w_{i}\right)+\beta_{3}\left(R d_{i}\right) \times\left(E f w_{i}\right)+\beta_{4}\left(X_{i}\right)+\mu_{i}
$$

where $i$ is country index, $\mu_{i}$ is the error term, $\Delta G d p$ is average annual growth in logged GDP per capita, $R d$ is resource dependence, $E f w$ is economic freedom as proxy for institutional quality, and $X$ is a vector of control variables.

Equation (5) is thus modified below in (7) using $I$, the institutional quality as proxied by $E f r$, index of economic freedom and Pri, public resource use index, while $X$ is, as earlier defined, vector of control variables. As such, in the functional, as well as natural log linear transformation forms, it gives, 


$$
\begin{aligned}
& \ln y_{t}=f\left(\ln _{t}, \ln X_{t}\right)=f\left(\ln E f r_{t}, \ln P r i_{t}, X_{t}\right) \\
& \ln y_{t}=\beta_{0}+\beta_{1} \ln E f r_{t}+\beta_{2} \operatorname{lnPri}_{t}+\beta_{3} X_{t}+\mu_{t}
\end{aligned}
$$

Thus, in order to establish the nature, magnitude and direction of the relationships among inclusive growth, government spending on education, government spending on health, economic freedom, CPIA public resource use index, and a control variable, real GDP growth rate in Nigeria, the following re-specifications in (8) and (9) are the empirical models for estimation. Therefore,

$$
\begin{aligned}
& \ln _{t}=f\left(\operatorname{lnGse}_{t}, G s h_{t}, \ln E f r_{t}, \ln P r i_{t}, G d p_{t}\right) \\
& \operatorname{lny}_{t}=\beta_{0}+\beta_{1} \ln G s e_{t}+\beta_{2} G s h_{t}+\beta_{3} \operatorname{lnEfr_{t}}+\beta_{4} \ln \operatorname{Pri}_{t}+\beta_{5} G d p_{t}+\varepsilon_{t}
\end{aligned}
$$

By a priori expectation, $\beta_{1}, \ldots, \beta_{6}>0$

Furthermore, as a general vector autoregressive (VAR) model of order $p$, in $Z_{t}$, where $Z_{t}$ is a column vector, an ARDL representation of equation (9) is formulated in the expression below as,

$$
\begin{aligned}
& \Delta\left(\operatorname{lny}_{t}\right)=\beta_{0}+\beta_{1} \operatorname{lny}_{t-1}+\beta_{2} \operatorname{lnGse}_{t-1}+\beta_{3} G s h_{t-1}+\beta_{4} \ln E f r_{t-1}+ \\
& \beta_{5} \ln P r i_{t-1}+\beta_{6} R g d p_{t-1}+\sum_{i=1}^{P} \beta_{1 i} \Delta\left(\operatorname{lny}_{t-1}\right)+\sum_{1=0}^{P} \beta_{2 i} \Delta\left(\ln G s e_{t-1}\right)^{+} \\
& \sum_{i=0}^{P} \beta_{3 i} \Delta\left(G_{s h} h_{t-1}\right)+\sum_{i=0}^{P} \beta_{4 i} \Delta\left(\ln E f r_{t-1}\right)+\sum_{i=0}^{P} \beta_{5 i} \Delta\left(\operatorname{lnPri} i_{t-1}\right)^{+} \\
& \sum_{i=0}^{P} \beta_{6 i} \Delta\left(\operatorname{Rgdp}_{t-1}\right)+\varepsilon_{t}
\end{aligned}
$$

where $\Delta$ is the first difference operator, $\beta_{0}$ is the drift component, and $\varepsilon_{\mathrm{t}}$ is white noise residual.

Essentially, the cointegration procedure follows the ARDL bounds testing approach. The test is mainly based on the joint Wald-test (F-statistic) which asymptotic distribution is non-standard under the null hypothesis of no cointegration among the variables. That is,

$$
\begin{aligned}
& H_{0}: \beta_{1}=\beta_{2}=\beta_{3}=\beta_{4}=\beta_{5}=\beta_{6}=0 \\
& H_{1}: \beta_{1} \neq \beta_{2} \neq \beta_{3} \neq \beta_{4} \neq \beta_{5} \neq \beta_{6} \neq 0 \quad \text { for } i=1,2,3,4,5,6 .
\end{aligned}
$$

However, two sets of critical values are fundamental for the cointegration test (see Pesaran et al, 2001). The first, lower critical bound which assumes that all the variables in the model are $\mathrm{I}(0)$, implies a no cointegration relationship. The second, upper critical bound assumes that all the variables in the model are I(1), implies that there is cointegration. Thus, if the F-statistic is less than the lower critical bound value, the null hypothesis, $H_{0}$ cannot be rejected. When the F-statistic exceeds the upper critical bound value, then there is cointegration and $H_{0}$ is rejected. A situation where the F-statistic falls between the two bounds, then the test is adjudged inconclusive. 
Moreover, the short-run dynamic parameters of the function can be obtained by estimating an error correction model version of the ARDL model in (10) as specified below in (11).

$\Delta\left(\operatorname{lny}_{t}\right)=\sum_{i=1}^{P} \beta_{1 i} \Delta\left(\ln y_{t-1}\right)+\sum_{i=0}^{P} \beta_{2 i} \Delta\left(\ln G s e_{t-1}\right)+\sum_{i=0}^{P} \beta_{3 i} \Delta\left(G s h_{t-1}\right) \quad+$ $\sum_{i=0}^{P} \beta_{4 i} \Delta\left(\operatorname{lnEfr}_{t-1}\right)+\sum_{i=0}^{P} \beta_{5 i} \Delta\left(\ln P r i_{t-1}\right)+\sum_{i=0}^{P} \beta_{6 i} \Delta\left(\operatorname{Rgdp}_{t-1}\right)+\lambda E C T_{t-1}+u_{t}$

where $\lambda$ is the speed of adjustment parameter and ECT is the residual obtained from equation (10).

\section{Variable Description, Measurement and Data Sources}

Inclusive growth has been suggested as a necessary and sufficient condition for achieving the Millennium Development Goals and is seen as essential for the post 2015 development agenda and the Sustainable Development Goals (SDGs). The proxy used for inclusive economic growth is GDP per capita based on PPP. GDP PPP is gross domestic product converted to international dollars using purchasing power parity rates. An international dollar has the same purchasing power over GDP as the U.S. dollar has in the United States. Data are in constant 2011 international dollars and sourced from World Bank, International Comparison Program database

Government spending is designed to build human and physical capital that will have long-term impact on economic growth, and therefore income, income distribution, and poverty. Government spending on education and health are effective levers of redistribution. As a proxy, government spending on education improves access to education which in turn can enhance inclusive growth by increasing individual productivity and facilitating the movement of poor people from low-paying jobs in agriculture to higher-paying jobs in industry and services. It is usually argued by policy makers that raising expenditure on education helps reduce income inequality. Government spending on health consists of recurrent and capital spending from all levels of governments budgets, external borrowings and grants (including donations from international agencies and nongovernmental organizations), and social (or compulsory) health insurance funds. This proxy also improves human productivity, in addition to physical and mental alertness. Data on education and health spending were collated from UNESCO Institute for statistics database, and World Health Organization Global Health Expenditure database.

As a proxy for institutional quality, economic freedom is described as the fundamental right of an individual to control his or her own labour and property. Such that, individuals are free to work, produce, consume, and invest in any way they please. The index is a composite measure based on ten quantitative and qualitative 
factors, namely: property rights, freedom from corruption; fiscal freedom, government spending; business freedom, labour freedom, monetary freedom; trade freedom, investment freedom, and financial freedom. Each of the freedoms is graded on a scale of 0 to 100 . An overall yearly score for a country is then derived as average of the ten economic freedoms. Data for the index were taken from Heritage Foundation data base.

Another proxy for institutional quality is the equity of public resource use which assesses the extent to which the pattern of public expenditures and revenue collection affects the poor and is consistent with national poverty reduction priorities. It is measured on a scale ranging from 1 to 6 (1=low to $6=$ high). The scale and data were obtained from country policy and institutional assessment (CPIA) data base.

Real GDP growth rate is the annual percentage growth rate of GDP whose aggregates are based on constant 2005 U.S. dollars. GDP is the sum of gross value added by all resident producers in the economy plus any product taxes and minus any subsidies not included in the value of the products. It is calculated without making deductions for depreciation of fabricated assets or for depletion and degradation of natural resources. Data for the variable were sourced from World Bank development research group and the Central Bank of Nigeria.

\section{Empirical Results and Discussion}

The result of the unit root test, as depicted in Table 1, shows that the series were integrated at $\mathrm{I}(0)$ and $\mathrm{I}(1)$. Specifically, the natural logarithms of inclusive growth (lny), government spending on education (lnGse), government spending on health (Gsh), and real GDP growth rate (Rgdp) were integrated at level, whilst natural logarithms of economic freedom (lnEfr) and public resources usage (lnPri) integrated at first difference. The $\mathrm{I}(0)$ and $\mathrm{I}(1)$ nature of the series necessarily confirmed the relevance and justification for the use of the ARDL cointegration approach.

Table 1: Dickey-Fuller GLS unit root test result

\begin{tabular}{|l|c|c|c|c|c|}
\hline Variable & Stage & Critical Value & $1 \%$ & $5 \%$ & $10 \%$ \\
\hline Lny & Level with Trend \& Intercept & -3.343660 & -3.770000 & -3.190000 & -2.890000 \\
\hline LnGse & Level with Trend \& Intercept & -3.611141 & -3.770000 & -3.190000 & -2.890000 \\
\hline Gsh & Level with Intercept & -2.036849 & -2.699769 & -1.961409 & -1.606610 \\
\hline LnEfr & 1st Difference with Intercept & -4.472890 & -2.708094 & -1.962813 & -1.606129 \\
\hline LnPri & 1st Difference with Intercept & -4.236236 & -2.708094 & -1.962813 & -1.606129 \\
\hline Rgdp & Level with Intercept & -2.962019 & -2.699769 & -1.961409 & -1.606610 \\
\hline
\end{tabular}

Source: Authors' computation 
The result of the long-run relationship is presented in Table 2. From the result, it was revealed, in conformity to the a priori expectation, that the coefficient of the immediate past value of inclusive growth was positively significant at the 5 per cent level. This confirmed the dynamic relevance of the ARDL model as past value of lny influenced its current value. Also, as expected, the coefficients of government spending on education, government spending on health, economic freedom, public resource usage, and real GDP growth rate were positive. More importantly, government spending on health, economic freedom, public resource use, and real GDP growth rate were significant at the 5 per cent level. However, government spending on education was not significant in the model. In addition, given the value of the F-statistic, the result further confirmed that the underlying ARDL regression, as specified in equation (13), was well fitted and the model was significant at the 5 per cent level.

Essentially, the result corroborates economic theory and previous findings $\mathrm{s}^{22}$ that economic freedom affects incentives, productive effort, and the effectiveness of resource use. Also, it follows, for example, White (2012), Adedeji et al (2013), and Huang and Quibria (2013) that a redistributive productive government spending on health and education spurs inclusive growth. Furthermore, since real GDP growth rate was significantly positive, it supports Habito (2009), Ianchovichina and Lundstrom (2009), and Klasen (2010) that inclusive growth is about raising the pace of growth and enlarging the size of the economy, benefit all stripes of society, including the poor, the near-poor, middle income groups, and even the rich.

Table 2: Long-run ARDL estimates. Dependent variable: lny

\begin{tabular}{|c|c|c|c|c|}
\hline Variable & Coefficient & Std. Error & t-statistic & Probability \\
\hline $\mathrm{C}$ & 0.564834 & 0.382033 & 1.478496 & 0.1393 \\
\hline $\ln Y(-1)$ & 0.888339 & 0.027186 & 32.67627 & 0.0000 \\
\hline $\operatorname{lnGse}(-1)$ & 0.008342 & 0.006392 & 1.305047 & 0.1919 \\
\hline $\operatorname{Gsh}(-1)$ & 0.015058 & 0.006301 & 2.248437 & 0.0462 \\
\hline $\operatorname{lnEfr}(-1)$ & 0.049270 & 0.105253 & 2.468116 & 0.0397 \\
\hline $\ln \operatorname{Pri}(-1)$ & 0.413987 & 0.077714 & 5.327046 & 0.0000 \\
\hline $\operatorname{Rgdp}(-1)$ & 0.012062 & 0.006188 & 2.247307 & 0.0461 \\
\hline $\operatorname{Adj} R^{2}$ & 0.94886 & & & \\
\hline F-statistic & 53.56804 & & & 0.0000 \\
\hline DW-statistic & 1.72214 & & & \\
\hline
\end{tabular}

Source: Author's computation

The short-run result, as tabulated in Table 3 , shows that the coefficient of the lagged error-correction term (ECT) was significant at 5 per cent level and had a negative sign, as expected. 
The ECT estimated value of -0.64 implies that the speed of adjustment to equilibrium after a shock was high. Such that, a disequilibrium from shock in the previous year converged quickly back to long-run equilibrium in the current year with an adjustment speed of 64 per cent, approximately. Also, in the short run, real GDP growth rate was positive and significant at the 5 per cent level, whereas economic freedom and public resource use, though positive, were both not significant. Meanwhile, one year-lagged value of inclusive growth, government spending on education, and public resource use were all negative and not significant.

Table 3: Short-run estimates. Dependent variable: $\Delta(\operatorname{lny})$

\begin{tabular}{|c|c|c|c|c|}
\hline Variable & Coefficient & Std. Error & $\mathrm{t}$-statistic & Probability \\
\hline $\mathrm{C}$ & -0.007179 & 0.014096 & -0.509301 & 0.6228 \\
\hline$\Delta(\ln Y(-1))$ & -0.006462 & 0.005675 & -2.138779 & 0.0842 \\
\hline$\Delta(\ln G \operatorname{se}(-1))$ & -0.024774 & 0.022956 & -1.079218 & 0.3086 \\
\hline$\Delta(\operatorname{Gsh}(-1))$ & 0.023791 & 0.081941 & 0.290344 & 0.7781 \\
\hline$\Delta(\operatorname{lnEfr}(-1))$ & 0.243276 & 0.123833 & 1.964552 & 0.0810 \\
\hline$\Delta(\ln \operatorname{Pri}(-1))$ & -0.019282 & 0.009526 & -2.024124 & 0.0736 \\
\hline$\Delta(\operatorname{Rgdp}(-1))$ & 0.975126 & 0.204277 & 4.773548 & 0.0010 \\
\hline ECT(-1) & -0.641071 & 0.210895 & -3.039762 & 0.0140 \\
\hline $\operatorname{Adj} R^{2}$ & 0.624691 & & & \\
\hline \multicolumn{2}{|l|}{ F-statistic } & & & 0.016506 \\
\hline DW-statistic & 2.167160 & & & \\
\hline
\end{tabular}

Source: Author's computation

Furthermore, the Wald test result in Table A2 in the appendix reports statistically significant F-statistic and Chi-square probability values of 0.0099 and 0.0003 , respectively. The F-statistic value of 6.560226 confirmed the presence of cointegration $^{23}$, thereby rejecting the null hypothesis. In the test for whether the residuals from the equation violated the normality assumption of the ordinary least squares (OLS) technique, the hypothesis of non-normality was rejected as the probability value of the Jarque-Berra statistic was 2.063577. Since the statistic is greater than the assumed level of significance of 0.05, as presented in Figure A1, the residuals were therefore normally distributed.

As reported in Table A1, based on the Akaike information criterion (AIC), the lag length selected was 2 . Thus, the result of the higher order serial correlation test, as shown in Table A3, implies that there was no serial correlation in the residuals up to the specified order of 2 . This was the case since the F-statistic and the Obs*R-squared were both not significant. Also, the result of the heteroscedasticity test affirmed the absence of heteroscedasticity in the residuals of the estimations as depicted in Table A4. 
The model also passed the stability tests as depicted in Figures 1 and 2, respectively where the cumulative sum of recursive residuals (CUSUM) and CUSUM of squares (CUSUMSQ) graphical illustrations show that the plots of the residuals did not cross the 5 per cent critical lines of parameter stability. This, in essence, implies the stability of the long-run parameters of government spending and inclusive growth function over the period 1995 to 2014 in Nigeria.

Figure 1: Graphical illustration of CUSUM

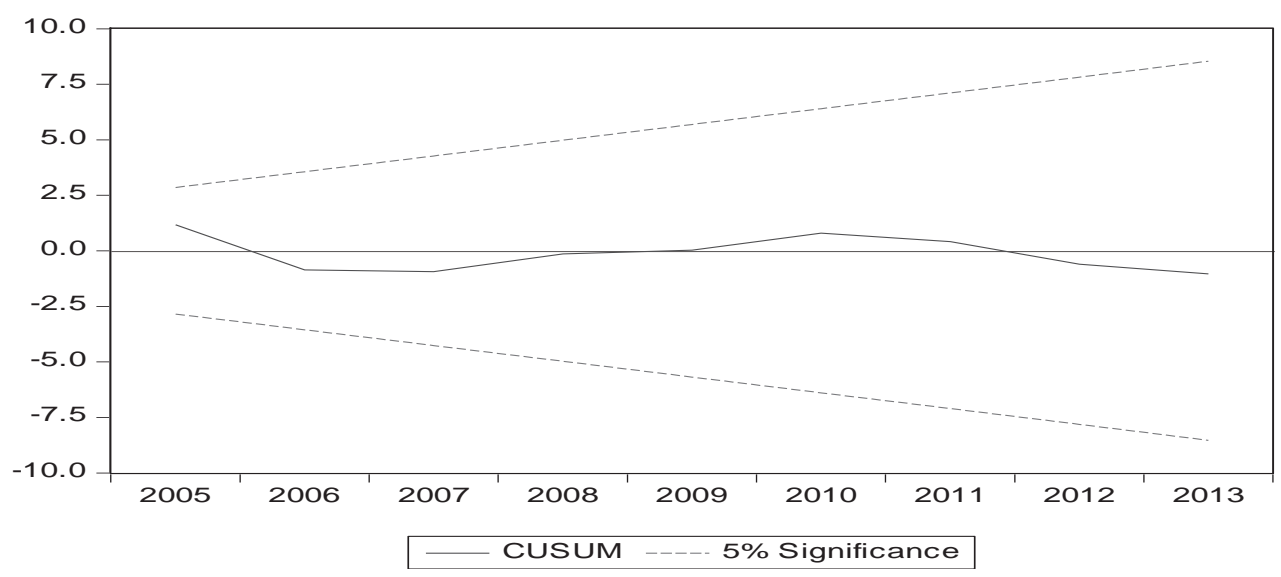

Figure 2: Graphical illustration of CUSUM of squares

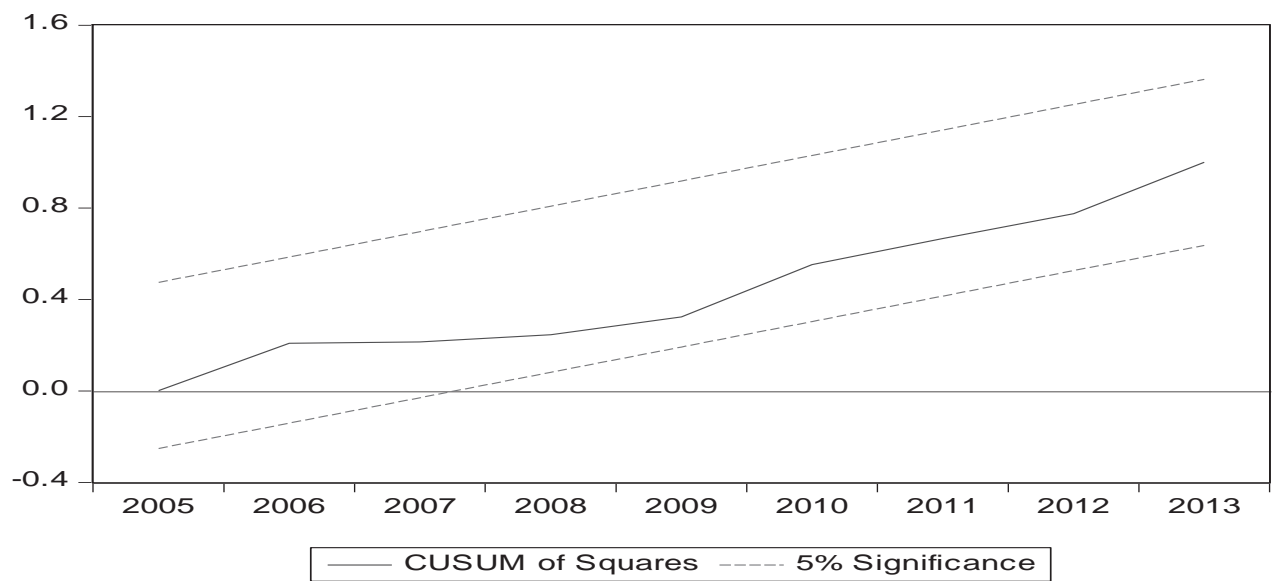

In addition, the test for specification errors was carried out using the Ramsey's regression specification error test (RESET). The result in Table A5 shows the absence of specification error as the test statistics were not significantly different from zero 
at the 5 per cent level of significance. Also, the estimated model would perform very well in forecasting given a close to zero Theil Inequality Coefficient at 0.000807 and a large Covariance Proportion of 0.873564 as shown in Figure A2.

\section{Conclusion, Policy Recommendations and Implications}

This study has examined the relationship between government spending and inclusive growth in Nigeria over the period 1995 to 2014. Specifically, it investigated how and to what extent government spending on education, government spending on health, economic freedom, public resource use, and real GDP growth rate have impacted on inclusive growth in the country. Using the ARDL technique, the study found that in the long-run government spending on health, economic freedom, public resource use and real GDP growth rate significantly influenced inclusive growth positively in Nigeria during the period considered. In the same period, government spending on education affected inclusive growth positively, but not significantly. In the short-run, however, only real GDP growth rate significantly impacted on inclusive growth in the country while other variables were not significant in causing inclusive growth. Thus, in conclution, government spending in the form of redistributive spending on health propelled inclusive growth in Nigeria.

In essence, from the findings, the government of Nigeria should direct its policy strategies on increasing productive government spending on health, education and infrastructure. For example, if government spending is increased on health by providing good quality drugs, qualified health personnel, clean and enabling environment, significant progress would be made at reducing water burn diseases, sexually transmitted diseases, malaria, polio, and so forth. Especially, infant mortality and maternal mortality would decline to a level less than 30 per thousand births and less than 100 per one hundred thousand live births across the country, respectively. In the same vein, an increased government spending on education would translate to improved level of primary and secondary schools rate of enrolment, academic excellence, research and development, human capital development, as well as skilled and productive work force. By extension, a high percentage of literate population would help cub spate of violence, militancy and insurgency across communities and regions in the country. By implication, people would have the sense of belonging and it would go a long way in causing inclusive growth in the country.

Essentially, infrastructure (public resource) enhances growth and development of a nation, apart from easing the well being of the people. Thus, since public resource use caused inclusive growth, if the government could provide infrastructural facilities such as good roads, electricity, water supply, communication, school and hospital buildings, productivity would improve. By implication, good roads would ease vehicular movement from production points to places of distribution. It would 
consequently reduce the cost of distribution and exchange as well as man-hour that could be lost in traffic grid locks. Electricity infrastructure would guarantee steady power supply to households, industries, recreation centres, and the streets. A constant power supply would help reduce cost of production and prices, but with large output across sectors of the economy. Water infrastructure would enhance the provision of pipe burn and potable water thereby eradicating the health risk associated with drinking of water from streams and other unsafe sources. In summary, provision of infrastructure would necessarily create more employment which in turn would translate to economic growth and social well-being.

Furthermore, government should formulate and implement institution-strengthening policies in the area of labour freedom, investment freedom, property rights, and other life enhancing programmes that can specifically help reduce inequality and poverty in the country. Government should strengthen the judicial institution to help dispense justice on time so that too much time, energy and money would not be wasted unnecessarily. Also, political institutions should be empowered and made independent in order to have a levelled playing field for contending political parties and candidates during elections. Institutions like the ICPC and EFCC should also be empowered with enough funds, qualified personnel and equipments. They must, in addition, be independent so that offenders could be prosecuted and charged appropriately.

Thus, if government implements all the above recommendations, economic growth will not only improve by creating jobs, and more income for the citizens, but it would be inclusive.

\section{REFERENCES}

Abuja Fact (2015). “Over 110 million Nigerians are living in poverty - VP Osinbajo". Retrieved from http://www.abujafacts.ng

Acemoglu, D., Johnson, S., \& Robinson, J.A. (2005). Institutions as the fundamental cause of longrun growth. In Aghion, P. and S. Durlauf (eds.) Handbook of Economic Growth. http://elsa. berkeley.edu/ chad/Handbook.html

Adedeji, O.S., Du, H., \& Opoku-Afari, M. (2013). Inclusive growth: An application of the social opportunity function to selected African countries. IMF Working Paper WP/13/139, International Monetary Fund

Adeniyi, O.M. \& Bashir, A.O. (2011). Sectoral analysis of the impact of public investment on economic growth in Nigeria (1970-2008). European Journal of Social Sciences, 20(2), 259.

Adewara, S.O. \& Oloni, E.F. (2012). Composition of public expenditure and economic growth in Nigeria. Journal of Emerging Trends in Economic Management Science, 3(4), 403-407.

African Economic Outlook. (2012). Nigeria 2012. Retrieved from http://www.africaneconomicoutlook.org

African Economic Outlook. (2014). Nigeria 2014. Retrieved from http://www.africaneconomicoutlook.org 
Agell, J., Lindh, T. \& Ohlsson, H. (1997). "Growth and the Public Sector: A Critical Review Essay". European Journal of Political Economy, 13, 33-52.

Akpan, N.I. (2005). Government expenditure and economic growth in Nigeria: A disaggregated approach. CBN Economic and Financial Review, 43(1), 51-69.

Al-Bataineh, I.M. (2012). The impact of government expenditures on economic growth in Jordan. Interdisciplinary Journal of Contemporary Research in Business, 4(6), 1320- 1338

Alexander, K. (2015). Inclusive growth: Topic guide. Birmingham, UK: GSDRC, University of Birmingham.

Ali, I., \& Son, H. H. (2007). "Measuring inclusive growth". Asian Development Review, 24(1), 11-31.

Alshahrani, S. \& Alsadiq, A. (2014). Economic growth and government spending in Saudi Arabia: An empirical investigation. IMF Working Paper WP/14/3

Aregbeyen, O., \& Kolawole, B.O. (2015). Oil revenue, public spending and economic growth relationships in Nigeria. Journal of Sustainable Development, 8(3), 113-123. doi:10.5539/jsd. v8n3p113

Aschauer, D. (1989a). "Is public expenditure productive?" Journal of Monetary Economics, 23, 177200.

Aschauer, D. (1989b). "Public investment and productivity growth in the group of seven." Economic Perspectives, 13, 17-25.

Aschauer, D. (1989c). "Does public capital crowd out private capital?" Journal of Monetary Economics, 24, 171-188.

Barro, R. (1990), "Government spending in a simple model of endogenous growth". Journal of Political Economy, 98, S103-S125.

Barro, R. (1991). "Economic growth in a cross-section of countries.” Quarterly Journal of Economics, $106,407-444$.

Barro, R.J. (1997). Determinants of economics growth: A cross-country empirical study. Cambridge and London, MIT Press

Béland, L-P., \& Tiagi, R. (2009). Economic freedom and the "resource curse: An empirical analysis. Studies in Mining Policy, Fraser Institute. Retrieved from www.fraserinstitute.org

Bourguignon, F. (2004). The Poverty-Growth-Inequality Triangle. Paper presented at the Indian Council for Research on International Economic Relations, New Delhi, on February 4.

Catholic Agency For Overseas Development (CAFOD) (2014). What is "inclusive growth"? CAFOD Discussion Paper (Full Version). Retrieved from www.cafod.org.uk/inclusive

Central Bank of Nigeria (2013). Statistical bulletin. Retrieved from www.cbn.gov.ng

Cole, J. H. (2003). The contribution of economic freedom to world economic growth, 1980-99. Cato Journal, 23(2), 189-198.

Collier, P. (2007). The bottom billion: Why the poorest countries are failing and what can be done about it. Oxford: Oxford University Press.

Country Policy and Institutional Assessment (CPIA) (2015). Available at http://www.indexmundi.com/ facts/topics/public-sector

De Haan, J., \& Sturm, J-E (2000). "On the Relationship between Economic Freedom and Economic Growth". European Journal of Political Economy, 16(2), 215-241.

Dickey, D.A., \& Fuller, W.A. (1979). "Distribution of the estimators for autoregressive time series with a unit root". Journal of the American Statistical Association, 74, 427-431.

Dobbs, R., Fiorini, R., Leke, A., Suleiman, A., Thompson, F., \& Wright, D. (2014). Nigeria's renewal: Delivering inclusive growth in Africa's largest economy. Prepublication document, McKinsey Global Institute

Easterly, W., \& Rebelo, S. (1993). "Fiscal policy and economic growth: An empirical investigation". Journal of Monetary Economics, 32, 417-458. 
Elliot, G., Rothenberg, T.J. \& Stock, J.H. (1996). "Efficient tests for an autoregressive unit root". Econometrica, 64, 813-36.

Engle, R.F. \& Granger, C.W.J. (1987). "Co-integration and error-correction: Representation, estimation and testing". Econometrica, 55, 251-276.

Evans, P., \& Karras, G. (1994). "Are government activities productive? Evidence from a panel of U.S. States". Review of Economics and Statistics, 76, 1- 11.

Fajingbesi, A.A., \& Odusola, A.F. (1999). Public expenditure and growth. A paper presented at a Training Programme on Fiscal Policy Planning Management in Nigeria, Organized by NCEMA, Ibadan, Oyo State. pp.137-179.

Garba, T. \& Abdullahi, S.Y. (2013). Public expenditure and economic growth: An application of cointegration and Granger causality tests on Nigeria. Journal of Economic and Social Research, 15(1), 1-30.

Gramlich, E. (1994), "Infrastructure investment: A review essay". Journal of Economic Literature, 32, 1176-1196.

Grier, K., \& Tullock, G. (1989). "An empirical analysis of cross-National economic growth, 19511980". Journal of Monetary Economics, 24, 259-276

Habito, C.F. (2009). 'Patterns of inclusive growth in Asia: Insights from an enhanced growth-poverty elasticity analysis.' ADBI Working Paper Series, No. 145. Tokyo, Asian Development Bank Institute.

Harris, R. \& Sollis, R. (2003). "Applied time series modelling and forecasting". Wiley, West Sussex.

Holtz-Eakin, D. (1994). "Public sector capital and productivity puzzle". Review of Economics and Statistics, 76, 12-21.

Huang, Y., \& Quibria, M.G. (2013). The global partnership for inclusive growth. WIDER Working Paper No. 2013/059, UNU-WIDER

Ianchovichina, E. \& Lundstrom, S. (2009). 'Inclusive growth analytics: Framework and application'. Policy Research Working Paper, No. 4851. Washington, DC, World Bank.

Ighodaro, C.A.U., \& Oriakhi, D.E. (2010). Does the relationship between government expenditure and economic growth follow Wagner's law in Nigeria? Annals of the University of Petrosani, Economics, 10(2), 185- 198.

Johansen, S. (1988). "Statistical analysis of cointegration vectors". Journal of Economics, Dynamics and Control, 12, 231-54.

Johansen, S. \& Juselius, K. (1990). "Maximum likelihood estimation and interference on cointegration with application to the demand for money". Oxford Bulletin of Economics and Statistics, 52, 169-210.

Klasen, S. (2010). 'Measuring and monitoring inclusive growth: Multiple definitions, open questions, and some constructive proposals'. ADB Sustainable Development Working Paper Series, No. 12. Mandaluyong City, Philippines, Asian Development Bank.

Kolawole, B.O. \& Odubunmi, S.A. (2015). Government capital expenditure, foreign direct investment and economic growth relationship in Nigeria, Mediterranean Journal of Social Sciences, 6(4S3), 444-453. Doi:10.5901/mjss.2015.v6n4s3p444

Kolawole, B.O., Omobitan, O.A. \& Yaqub, J.O. (2015). Poverty, inequality and rising growth in Nigeria: Further empirical evidence. International Journal of Economics and Finance, 7(2), 51-62. doi.org/10.5539/ijef.v7n2p

Kormendi, R. \& Meguire, P. (1985). "Macroeconomic determinants of growth: Cross- country evidence". Journal of Monetary Economics, 16, 141-163.

Landau, D. (1986). "Government and economic growth in less developed countries: An empirical study for 1960-1980". Economic Development and Cultural Change, 35, 35-75.

Levine, R., \& Renelt, D. (1992). “A sensitivity analysis of cross-country growth regressions”. American Economic Review, 82, 942-963. 
Mahmood, K., Azid, T., Chaudhry, I.M., \& Faridi, M.Z. (2010). Impact of economic freedom on economic growth: The case of some selected SAARC member countries. International Research Journal of Finance and Economics, 52, 7-16.

Mckay, A. \& Sumner, A. (2008). Economic growth, inequality and poverty reduction: Does pro-poor growth matter? Issue 03, Concern for the Bottom Billion, IDS In Focus, Research and Analysis from the Institute of Development Studies.

McKinley, T. (2010). 'Inclusive growth criteria and indicators: An inclusive growth index for diagnosis of country progress'. ADB Sustainable Development Working Paper Series, No. 14. Mandaluyong City, Philippines, Asian Development Bank.

Morrison, C. \& Schwartz, A. (1996). "State infrastructure and productive performance". American Economic Review, 86, 1095-1111.

Munell, A. (1992). "Infrastructure investment and economic growth". Journal of Economic Perspectives, 6, 189-198.

Muse, B.O., Olorunleke, K. \& Alimi, R.S. (2013). The effect of Federal government size on economic growth in Nigeria, 1961-2011. Developing Country Studies, 3(7), 68-76.

Narayan, P. (2005). "The saving and investment nexus for China: Evidence from cointegration Tests." Applied Economics, 37(17), 1979-1990.

Nasiru, I. (2012). Government expenditure and economic growth in Nigeria: Cointegration analysis and causality testing. Academic Research International, 2(3), 718-723.

North, Douglass C. (1990). Institutions, institutional change and economic performance. Cambridge University Press.

Nurudeen, A. \& Usman, A. (2010). Government expenditure and economic growth in Nigeria, 19702008: A disaggregated analysis. Business Economics Journal, 4, 1-11.

Ogiogio, G.O. (1995). Government expenditure and economic growth in Nigeria. Journal of Economic Management, 2(1), 1

Oni, L.B., Aninkan, O.O. \& Akinsanya, T.A. (2014). Joint effects of capital and recurrent expenditures in Nigeria's economic growth. European Journal of Globalization and Development Research, 9(1), 530-543.

Oyinlola, M.A., \& Akinnibosun, O. (2013). Public expenditure and economic growth nexus: Further evidence from Nigeria. Journal of Economics and International Finance, 5(4), 146-154. doi:10.5897/0489

Pesaran, H.M., \& Shin, Y. (1999). Autoregressive distributed lag modelling approach to cointegration analysis. In Storm, S. (ed.), Econometric and Economic Theory in the $20^{\text {th }}$ Century (Chapter 11). The Ragner Frisch Centennial Symposium, Cambridge University Press, Cambridge.

Pesaran, M.H., Shin, Y., \& Smith, R.J. (2001). "Bounds testing approaches to the analysis of level relationship." Journal of Applied Economics, 16, 289-326.

Phillips, P.C.B., \& Perron, P. (1988). "Testing for a unit root in time series regression.” Biometrika, 75, 335-346.

Powell, B. (2003). Economic freedom and growth: The case of the celtic tiger. Cato Journal, 22(3), 431-448.

Ram, R. (1986). "Government size and economic growth: A new framework and some evidence from cross-section and time-series data". American Economic Review, 76, 191-203.

Ratner, J. (1983). "Government capital and the production function for U.S. private output". Economics Letters, 13, 213-217.

Slemrod, J. (1995). "What do cross-country studies teach about government involvement, prosperity, and economic growth?" Brookings Papers on Economic Activity, 2, 373-431.

Stuart, E. (2011). "Making growth inclusive: Some lessons for countries and the literature." Oxfam Research Report, April; Working Paper, September (Oxford:: Oxfam International). 
Sturm, J. \& De Haan, J. (1995). "Is public expenditure really productive? New evidence for the USA and the Netherlands". Economic Modelling, 12, 60-72.

Suryanarayana, M.H. (2013). Inclusive growth: A sustainable perspective. Indira Gandhi Institute of Development Research, United Nations Development Programme, India.

The Heritage Foundation (2012). Index of economic freedom. Available at http://www.heritage.org/ index/pdf/2012/book/index_2012.pdf

The Sun (2015). “110m Nigerians are poor - Osinbajo". Retrieved from http://sunnewsonline.com/new

United Nations Development Programme (2010). Human development report. Retrieved from http:// hdr.undp.org/sites/default/files/reports/270/hdr_2010_en_complete_reprint.pdf

United Nations Development Programme (2013). Human development report: The rise of the south: Human progress in a diverse world. Retrieved from http://hdr.undp.org/sites/default/files/reports/14/hdr2013_en_complete.pdf

UNESCO (2010). Education for all global monitoring report: Reaching the marginalized. Retrieved from http://unesdoc.unesco.org/images/0018/001866/186606E.pdf

UNESCO (2012). Education for all global monitoring report: Youth and skills: Putting education to work. Retrieved from http://unesdoc.unesco.org/images/0021/002180/218003e.pdf

UNESCO Institute for statistics database (2012). Retrieved from http://www.uis.unesco.org/Pages/default.aspx

Usman, A., Mobolaji, H.I., Kilishi, A.A. Yaru, M.A. \& Yakubu, T.A. (2011). Public expenditure and economic growth in Nigeria. Asian Economic and Financial Review, 1(3), 104-113.

Wagner, Adolph (1890). Finanzwissenschaft, Leipig, Germany.

White, W.R. (2012). 'Policy debate: How do you make growth more inclusive?' In L. de Mello and M.A. Dutz (eds), Promoting inclusive growth: Challenges and policies. Paris, OECD Publishing.

World Bank (2009). "What is inclusive growth?" World Bank, Washington DC

World Bank (2014). CPIA equity of public resource use rating. Retrieved from http://www.worldbank. org/ida

World Health Organization Global Health expenditure database. Retrieved from http://apps.who.int/ nha/database

\section{APPENDIX}

Table A1: VAR lag order selection criteria

Sample: $19952014 . \quad$ Included observations: 18

\begin{tabular}{|c|c|c|c|c|c|c|}
\hline Lag & LogL & LR & FPE & AIC & SC & HQ \\
\hline 0 & 43.69764 & NA & $6.11 \mathrm{e}-10$ & -4.188626 & -3.891836 & -4.147703 \\
\hline 1 & 62.41164 & 54.82075 & $1.23 \mathrm{e}-13 *$ & -12.96053 & -10.88300 & -12.67407 \\
\hline 2 & 158.6448 & $140.4910 *$ & $4.15 \mathrm{e}-41$ & $-37.10362 *$ & $-31.65507 *$ & $-36.8076^{*}$ \\
\hline
\end{tabular}

* indicates lag order selected by the criterion

Table A2: Wald test

\begin{tabular}{|l|c|c|c|}
\hline Test Statistic & Value & df & Probability \\
\hline F-statistic & 6.560226 & $(6,11)$ & 0.0099 \\
\hline Chi-square & 24.96136 & 6 & 0.0003 \\
\hline
\end{tabular}

Null Hypothesis: $C(1)=C(2)=C(3)=C(4)=C(5)=C(6)=0$ 
Table A3: Breusch-Godfrey serial correlation LM test

\begin{tabular}{|l|l|l|l|}
\hline F-statistic & 0.609656 & Prob. F(2,9) & 0.5645 \\
\hline Obs*R-squared & 2.147661 & Prob. Chi-Square(2) & 0.3417 \\
\hline
\end{tabular}

Test Equation:

Dependent Variable: RESID

Method: Least Squares

Date: 19/06/16 Time: 18:20

Sample: 19962014

Included observations: 18

Presample missing value lagged residuals set to zero.

\begin{tabular}{|c|r|r|r|r|}
\hline Variable & Coefficient & Std. Error & t-Statistic & Prob. \\
\hline C & -0.027823 & 0.387581 & -0.071785 & 0.9443 \\
\hline LGSE(-1) & -0.000947 & 0.008398 & -0.112785 & 0.9127 \\
\hline GSH(-1) & -0.003293 & 0.022996 & -0.143208 & 0.8893 \\
\hline LEFR(-1) & 0.000222 & 0.102840 & 0.002160 & 0.9983 \\
\hline LPRI(-1) & 0.048398 & 0.139182 & 0.347736 & 0.7360 \\
\hline LRGDP(-1) & -0.001615 & 0.015893 & -0.101594 & 0.9213 \\
\hline LGPC(-1) & -0.001714 & 0.038736 & -0.044243 & 0.9657 \\
\hline RESID(-1) & -0.007799 & 0.488152 & -0.015977 & 0.9876 \\
\hline RESID(-2) & -0.385673 & 0.351040 & -1.098658 & 0.3004 \\
\hline R-squared & 0.119314 & Mean dependent var & $2.91 \mathrm{E}-15$ \\
\hline Adjusted R-squared & -0.663517 & S.D. dependent var & 0.013235 \\
\hline S.E. of regression & 0.017070 & Akaike info criterion & -4.996157 \\
\hline Sum squared resid & 0.002622 & Schwarz criterion & -4.550971 \\
\hline Log likelihood & 53.96541 & \multicolumn{2}{|c|}{ Hannan-Quinn criter. } & -4.934772 \\
\hline F-statistic & 0.152414 & \multicolumn{2}{|c|}{ Durbin-Watson stat } & 2.005325 \\
\hline Prob(F-statistic) & 0.992814 & \multicolumn{5}{|l}{} \\
\hline
\end{tabular}

Table A4: Heteroskedasticity test: Breusch-Pagan-Godfrey

\begin{tabular}{|l|l|l|r|}
\hline F-statistic & 0.372387 & Prob. F(6,11) & 0.8817 \\
\hline Obs*R-squared & 3.038903 & Prob. Chi-Square(6) & 0.8039 \\
\hline Scaled explained SS & 1.798858 & Prob. Chi-Square(6) & 0.9372 \\
\hline
\end{tabular}

Test Equation:

Dependent Variable: RESID ${ }^{\wedge} 2$

Method: Least Squares

Date: 19/06/16 Time: 18:23

Sample: 19962014

Included observations: 18

\begin{tabular}{|c|r|r|r|r|}
\hline Variable & Coefficient & Std. Error & t-Statistic & Prob. \\
\hline C & -0.003048 & 0.007540 & -0.404212 & 0.6938 \\
\hline LGSE(-1) & $3.30 \mathrm{E}-05$ & 0.000157 & 0.210220 & 0.8373 \\
\hline GSH(-1) & 0.000168 & 0.000415 & 0.405484 & 0.6929 \\
\hline
\end{tabular}




\begin{tabular}{|l|r|r|r|r|}
\hline \multicolumn{1}{|c|}{ LEFR(-1) } & 0.001691 & 0.002013 & 0.839660 & 0.4190 \\
\hline LPRI(-1) & -0.000934 & 0.002493 & -0.374760 & 0.7150 \\
\hline LRGDP(-1) & 0.000115 & 0.000254 & 0.454139 & 0.6586 \\
\hline LGPC(-1) & -0.000386 & 0.000778 & -0.495959 & 0.6297 \\
\hline R-squared & 0.168828 & Mean dependent var & 0.000165 \\
\hline Adjusted R-squared & -0.284539 & S.D. dependent var & 0.000303 \\
\hline S.E. of regression & 0.000344 & Akaike info criterion & -12.82947 \\
\hline Sum squared resid & $1.30 \mathrm{E}-06$ & Schwarz criterion & -12.48321 \\
\hline Log likelihood & 122.4652 & Hannan-Quinn criter. & -12.78172 \\
\hline F-statistic & 0.372387 & Durbin-Watson stat & 2.699170 \\
\hline Prob(F-statistic) & 0.881742 & & & \\
\hline
\end{tabular}

\section{Table A5: Ramsey RESET test}

Specification: LGPC C LGSE(-1) GSH(-1) LEFR(-1) LPRI(-1) LRGDP(-1) LGPC(1)

Omitted Variables: Squares of fitted values

\begin{tabular}{|l|c|c|c|}
\hline & Value & df & Probability \\
\hline t-statistic & 1.161106 & 10 & 0.2726 \\
\hline F-statistic & 1.348166 & $(1,10)$ & 0.2726 \\
\hline Likelihood ratio & 2.276479 & 1 & 0.1313 \\
\hline
\end{tabular}

Figure A1: Result of the normality test

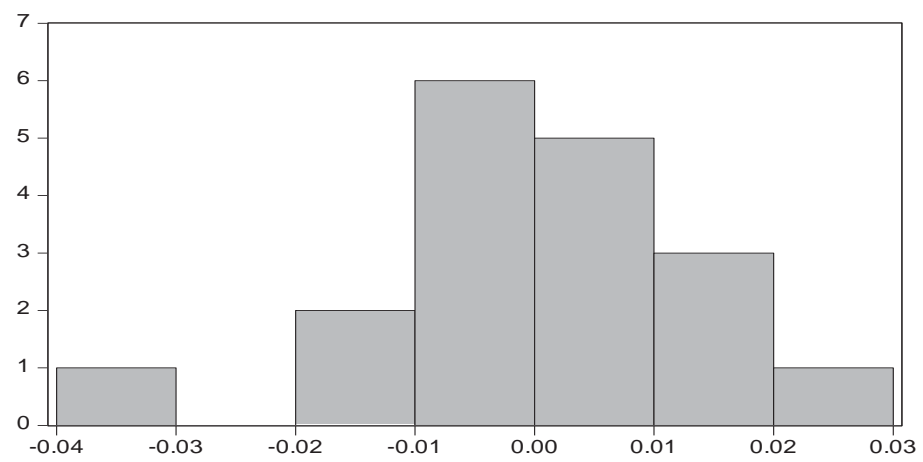

\begin{tabular}{|lr|}
\hline \multicolumn{2}{|l|}{ Series: Residuals } \\
Sample 1996 2013 \\
Observations 18 \\
Mean & $2.91 \mathrm{e}-15$ \\
Median & -0.000782 \\
Maximum & 0.024358 \\
Minimum & -0.035020 \\
Std. Dev. & 0.013235 \\
Skewness & -0.587869 \\
Kurtosis & 4.170076 \\
& \\
Jarque-Bera & 2.063577 \\
Probability & 0.356369 \\
\hline
\end{tabular}


Figure A2: Dynamic forecast illustration

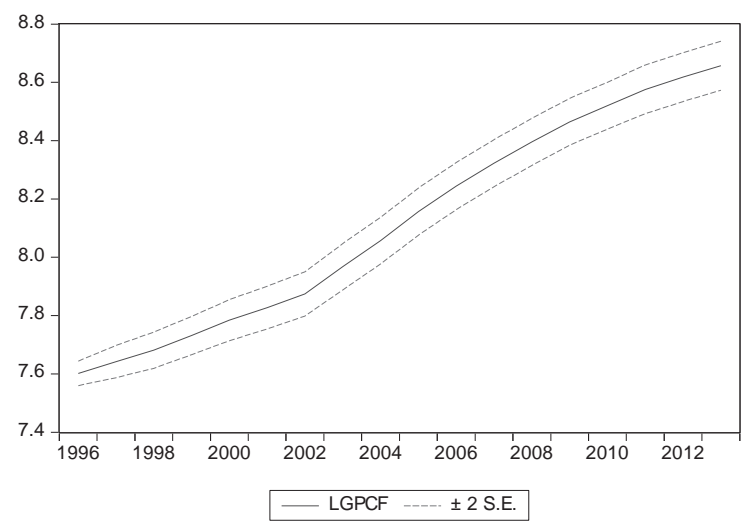

Forecast: LGPCF

Actual: LGPC

Forecast sample: 19952013

Adjusted sample: 19962013

Included observations: 18

Root Mean Squared Error $\quad 0.013110$

Mean Absolute Error $\quad 0.008266$

Mean Abs. Percent Error $\quad 0.103312$

Theil Inequality Coefficient 0.000807

Bias Proportion $\quad 0.000272$

Variance Proportion $\quad 0.126164$

Covariance Proportion $\quad 0.873564$

\section{ENDNOTES}

${ }^{1}$ See Collier (2007)

${ }^{2}$ See Stuart (2011)

${ }^{3}$ See Wagner (1883)

${ }^{4}$ See Gramlich (1994)

${ }^{5}$ See Barro (1991)

${ }^{6}$ See Mckay \& Summer (2008)

${ }^{7}$ See African Economic Outlook (2014)

${ }^{8}$ See Dobbs et al (2014)

${ }^{9}$ See Abuja Fact (2015) and The Sun (2015)

${ }^{10}$ Studies which include Ighodaro \& Oriakhi (2010) and Oyinlola \& Akinnibosun (2013)

${ }^{11}$ See Barro (1997), and Acemoglu, Johnson \& Robinson (2005)

${ }^{12}$ See The Sun Newspaper (2015)

${ }^{13}$ See UNDP $(2010,2013)$

${ }^{14}$ This conceptualisation draws and expands the definition of inclusive growth by Habito (2009)

${ }^{15}$ See Ratner (1983), Kormendi \& Meguire (1985), Ram (1986), Aschauer (1989 a,b,c), Munell (1992), Easterly \& Rebelo (1993), and Morrison \& Schwartz (1996)

${ }^{16}$ See Levine \& Renelt (1992), Holtz-Eakin (1994), Sturm \& De Haan (1995), Slemrod (1995), Agell, Lindh \& Ohlsson (1997)

${ }^{17}$ See Klasen (2010); McKinley (2010); and Alexander (2015)

${ }^{18}$ Ianchovichina \& Lundstrom (2009).

${ }^{19}$ As alternative to the widely used methods of Dickey \& Fuller (1979), and Phillips \& Perron (1988)

${ }^{20}$ Engle \& Granger (1987); Johansen (1988); and Johansen \& Joselius (1990)

${ }^{21}$ See Harris \& Sollis (2003)

${ }^{22}$ Findings of, for example, De Haans \& Sturm (2000), Cole (2003), Powel (2003), and Mahmood et al (2010).

${ }^{23}$ See Tables for critical values in Pesaran et al (2001), and Narayan (2005) 